\title{
Protection against pulmonary infection with Klebsiella pneumoniae in mice by interferon- $\gamma$ through activation of phagocytic cells and stimulation of production of other cytokines
}

\author{
KANAKO YOSHIDA, TETSUYA MATSUMOTO*, KAZUHIRO TATEDA*, KOU UCHIDA, \\ SHIRO TSUJIMOTO†, YOICHIRO IWAKURA
}

Departments of Internal Medicine II, *Microbiology and + Hospital Pathology, Toho University School of Medicine, Omori-Hishi, Ota-ku, Tokyo and \$Center for Experimental Medicine, Institute of Medical Science, University of Tokyo, Tokyo, Japan

\begin{abstract}
The study was designed to determine the role of interferon (IFN)- $\gamma$ in inflammatory responses against experimentally induced pneumonia caused by Klebsiella pneumoniae. The host immunological responses in IFN- $\gamma$ gene knockout $\left(\right.$ IFN- $\gamma^{-/-}$) mice and immunocompetent control mice were compared. $K$. pneumoniae strain T-113 was inoculated intranasally into anaesthetised mice to induce pneumonia. Infected control mice survived significantly longer than infected IFN- $\gamma^{-/-}$mice. Viable bacterial counts in lungs and blood abruptly increased in IFN- $\gamma^{-/-}$mice; in contrast, a gradual decrease in the number of bacteria was noted in control mice. During the early stages of infection, the concentrations of interleukin (IL)-1 $\beta$ and IL-6 in broncho-alveolar lavage fluid and IL-1 $\beta$ in serum of IFN- $\gamma^{-/-}$mice were significantly lower than in control mice. During the late stage of infection, serum IL-6 level in IFN- $\gamma^{-/-}$mice was significantly higher than in control mice. These results suggest that the defective immunological host response, including inflammatory cytokine production caused by deficiency of IFN- $\gamma$, is one of the mechanisms that allow the progression of pulmonary infection to systemic septicaemia.
\end{abstract}

\section{Introduction}

Klebsiella pneumoniae, a capsulate gram-negative bacterium, is one of the most important causative pathogens of respiratory tract infections in man [1]. Pneumonia caused by this organism is an expansive and voluminous pneumonia characterised by destruction of alveolar septa. This type of pneumonia is often difficult to treat, particularly in debilitated patients, and the associated mortality rate is $20-54 \%$ [2-5]. Effective host defence against $K$. pneumoniae infection depends on non-specific immunological responses, which are mediated by phagocytic cells, including neutrophils and macrophages.

The recruitment and activation of leucocytes in the setting of bacterial challenge is a complex and dynamic

Received 22 Feb. 2001; revised version received 20 April 2001; accepted 20 April 2001.

Corresponding author: Dr K. Yoshida (e-mail: kanako@med. tohu-u.ac.jp). process involving the co-ordinated expression of both pro- and anti-inflammatory cytokines including interferon (IFN) $-\gamma$ [6-10]. The results of studies of IFN- $\gamma$ treatment have shown effective antimicrobial activity of IFN- $\gamma$ in mice with wound [11] and pulmonary [12] infections caused by $K$. pneumoniae. Furthermore, studies employing animals genetically unable to produce or respond to IFN- $\gamma$ have revealed that the antimicrobial activity of IFN- $\gamma$ is reduced in IFN- $\gamma$ knockout mice infected with Mycobacterium bovis, Leishmania major, Listeria monocytogenes, Streptococcus pneumoniae and Candida albicans [13-17].

One of the suggested mechanisms of the protective action of IFN- $\gamma$ is activation of phagocytic cells. IFN- $\gamma$ can also induce the production of other inflammatory cytokines. The present study investigated whether the greater susceptibility to $K$. pneumoniae infection in IFN- $\gamma$ knockout mice was due not only to the deficiency of IFN- $\gamma$, but also to reduced production of other cytokines. For this purpose, the kinetics of various inflammatory cytokines in IFN- $\gamma$ gene knock- 
out mice with pulmonary infection caused by $K$. pneumoniae were investigated.

\section{Materials and methods}

Animals

Specific pathogen-free, IFN- $\gamma$ gene knockout mice (IFN- $\gamma^{-/-}$mice) on a BALB/cA background, and corresponding control $\mathrm{BALB} / \mathrm{cA}$ male mice, 8-9 weeks old and weighing $22-25 \mathrm{~g}$, were used in the present study. Control mice were obtained from Japan Clea Co. (Osaka, Japan). All mice were housed in a pathogen-free environment within the animal care facility at Toho University. The experimental protocol was approved by the Ethics Review Committee for Animal Experimentation of Toho University School of Medicine.

\section{Bacteria}

K. pneumoniae strain $\mathrm{T}-113$, a clinical isolate from sputum of a patient with pneumonia, was used. The strain was kept frozen at $-80^{\circ} \mathrm{C}$ in brain-heart infusion (BHI) broth containing glycerol 15\%.

\section{Pulmonary infection with K. pneumoniae}

Bacteria grown on $\mathrm{BHI}$ agar for $24 \mathrm{~h}$ at $37^{\circ} \mathrm{C}$ were suspended in sterile saline and adjusted to a density of $1 \times 10^{8} \mathrm{cfu} / \mathrm{ml}$. After each mouse was anaesthetised with $0.1 \mathrm{ml}$ of xylazine, ketamine-HCl and saline mixture by intradermal administration, $40 \mu \mathrm{l}$ of bacterial suspension containing $4 \times 10^{3} \mathrm{cfu}$ of $K$. pneumoniae were inoculated intranasally. The animal's survival was recorded every $24 \mathrm{~h}$ until 14 days after inoculation $(\mathrm{n}=16$ in each group).

\section{Determination of viable bacterial counts in blood and lung tissues}

Mice were killed by ether inhalation and cardiac blood samples were collected under sterile conditions $(n=8$ in each group). Lungs were removed aseptically and homogenised with a tissue homogeniser in $5 \mathrm{ml}$ of sterile saline. Blood and homogenised lung samples were serially diluted with sterile saline and plated on BHI agar plates. After incubation for $24 \mathrm{~h}$ at $37^{\circ} \mathrm{C}$, bacterial colonies were counted and viable bacterial counts were calculated. The remaining blood samples were allowed to clot at $4^{\circ} \mathrm{C}$ and then centrifuged at $15000 \mathrm{rpm}$ for $1 \mathrm{~min}$. Serum samples were preserved at $-80^{\circ} \mathrm{C}$ until measurement of cytokines.

\section{Broncho-alveolar lavage}

Broncho-alveolar lavage (BAL) was performed in each mouse ( $\mathrm{n}=8$ in each group). The mice were killed by deep ether anaesthesia followed by immediate exposure of the trachea. Mice were intubated with a polyethylene catheter $(\mathrm{OD}, 1.0 \mathrm{~mm})$ and BAL was performed with $1 \mathrm{ml}$ of sterile saline; c. $0.5-0.6 \mathrm{ml}$ of BAL fluid (BALF) was retrieved from each mouse. Lavage fluid was centrifuged at $10000 \mathrm{rpm}$ for $5 \mathrm{~min}$. Supernates were collected and stored at $-80^{\circ} \mathrm{C}$ for assessment of cytokine levels.

\section{Histopathological examination}

Lungs were fixed with formaldehyde $3.7 \%$ solution, then $4-\mu \mathrm{m}$ thick sections were cut, stained with haematoxylin and eosin and examined by light microscopy.

\section{Measurement of cytokine concentrations}

The concentrations of murine interleukin (IL)- $1 \beta$ and IL-6 in serum and BALF ( $\mathrm{n}=8$ in each group) were determined with enzyme-linked immunosorbent assay (ELISA) kits purchased from Genzyme (Cambridge, MA, USA) and Biosource International (Camarillo, CA, USA), respectively. Assays were performed according to the protocols recommended by the manufacturers.

\section{Statistical analysis}

Data were expressed as mean (SEM). Differences in survival rates were analysed by the log rank test, whereas differences in the number of bacteria and cytokine levels were analysed by the Mann-Whitney U test. Differences were considered statistically significant if $\mathrm{p}$ values were $<0.05$.

\section{Results}

\section{Survival of mice after pulmonary infection with} $K$. pneumoniae

IFN- $\gamma^{-/-}$mice developed signs of septicaemia, including lethargy, decreased food intake and ruffled fur, 3 days after intranasal inoculation of strain T-113. Significant and progressive respiratory distress developed 4 days after inoculation of bacteria. As shown in Fig. 1 , only $20 \%$ of IFN- $\gamma^{-/-}$mice were still alive at 14 days after inoculation, compared with $60 \%$ survival in control mice. There was a significant difference in the survival rate between IFN- $\gamma^{-/-}$mice and control mice $(\mathrm{p}<0.01)$.

\section{Bacterial clearance}

As shown in Fig. 2a, the number of viable $K$. pneumoniae isolated from the lungs of infected IFN$\gamma^{-/-}$mice increased abruptly on day 4 , whereas the bacteria were readily cleared from the lungs of immunocompetent mice and the bacterial count was below the detection limit at the same time interval. Data indicated significant differences in viable bacterial counts in lungs between these two groups of mice at 2 , 


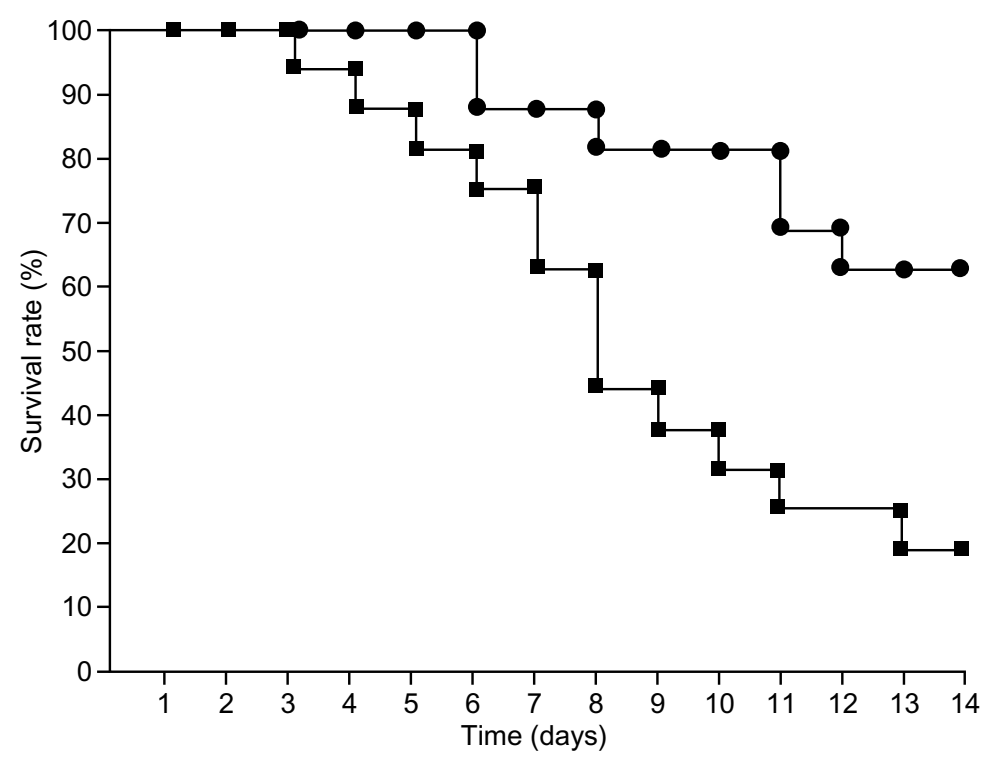

Fig. 1. Survival rate of mice with experimentally induced pulmonary infection caused by $K$. pneumoniae. Mice were inoculated intranasally with $40 \mu \mathrm{l}$ of bacterial suspension containing $4 \times 10^{3}$ cfu of $K$. pneumoniae. $\mathbf{m}$, IFN- $\gamma^{-/-}$mice; - control mice $\left(\mathrm{n}=16\right.$ for each group). $\mathrm{p}<0.01$, IFN- $\gamma^{-/-}$mice versus control mice.

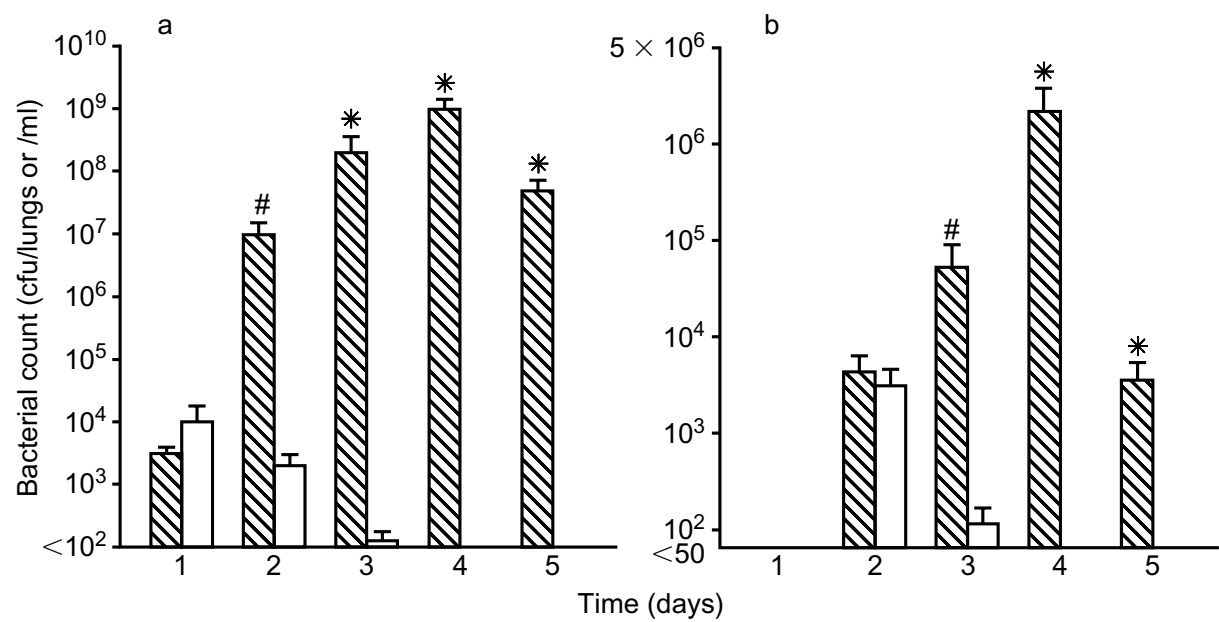

Fig. 2. (a) Viable bacterial counts in lungs of mice after pulmonary inoculation of $K$. pneumoniae. (b) Viable bacterial counts in blood of mice after pulmonary inoculation of $K$. pneumoniae. Data are mean and SEM values $(\mathrm{n}=8$ mice in

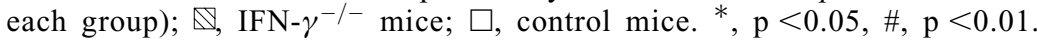

3,4 and 5 days after infection. The number of viable bacteria in the blood of IFN- $\gamma^{-/-}$mice increased from day 2 to day 4, whereas $K$. pneumoniae was detected in blood of control mice only on days 2 and 3 (Fig. 2b). The number of viable $K$. pneumoniae isolated from blood of infected IFN- $\gamma^{-/-}$mice was significantly greater than that from infected control mice on days 3 , 4 and 5.

\section{Histopathological findings}

Histopathological examination of sections of lungs of IFN- $\gamma^{-/-}$mice killed $48 \mathrm{~h}$ after inoculation of $K$. pneumoniae demonstrated acute broncho-alveolar pneumonia with inflammatory cell infiltration into alveolar spaces and interstitial tissues and alveolar spaces packed with $K$. pneumoniae expressing a thick capsule (Fig. 3a). On the other hand, lungs of control mice showed mild infiltration of inflammatory cells, mainly into interstitial tissues (Fig. 3b).

\section{Kinetics of inflammatory cytokines in serum and $B A L F$}

During the acute stage of infection (up to $24 \mathrm{~h}$ after inoculation), significantly lower IL- $1 \beta$ concentrations were detected in BALF of IFN- $\gamma^{-/-}$mice, compared with those of control mice. Furthermore, IL-6 concentrations in BALF of IFN- $\gamma^{-/-}$mice were also significantly lower than in control mice at 12 and $24 \mathrm{~h}$ 

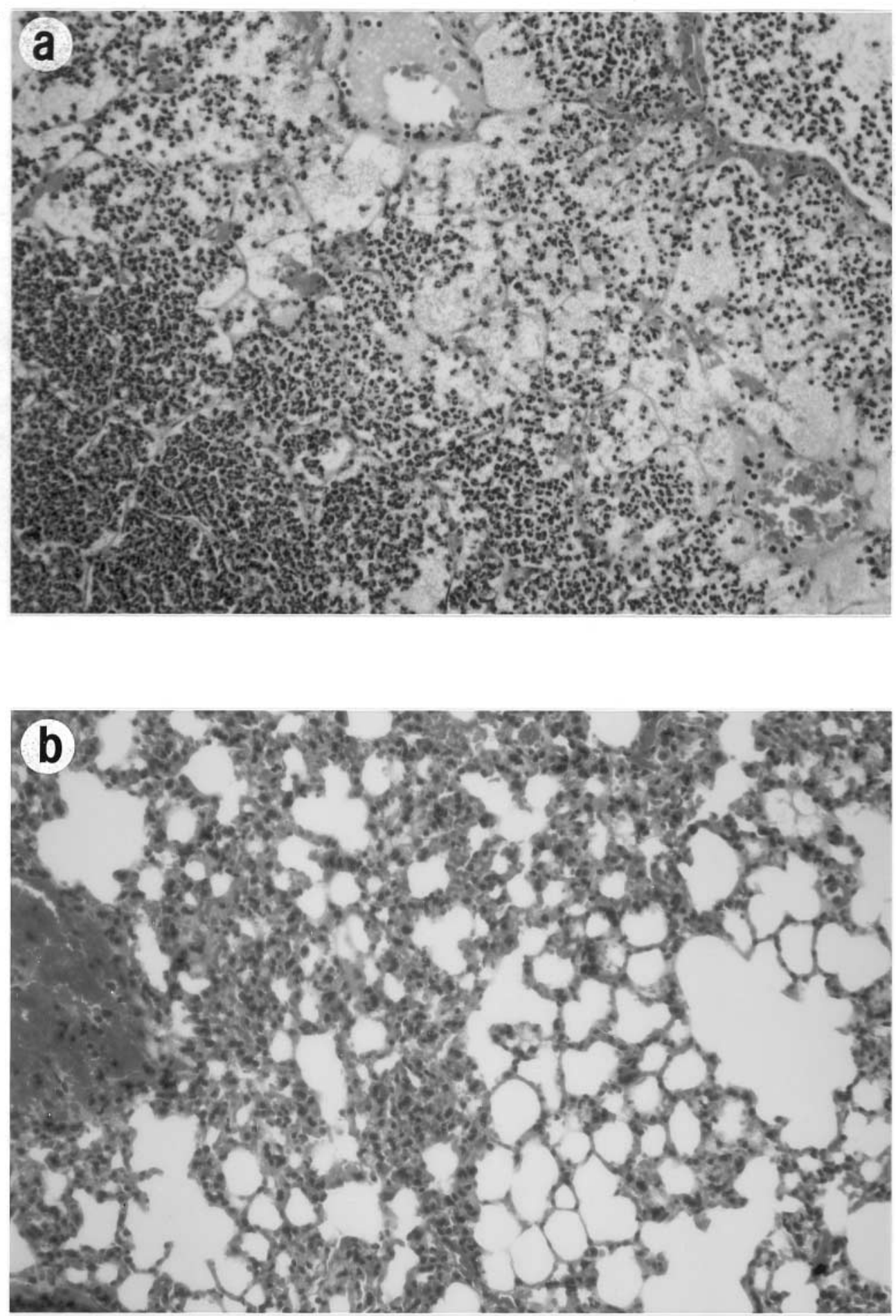

Fig. 3. Histological sections of lungs of representative IFN- $\gamma^{-/-}$and control mice killed $48 \mathrm{~h}$ after intranasal administration of $K$. pneumoniae. (a) IFN $-\gamma^{-/-}$mouse. Note the presence of bronchopneumonia manifested by inflammatory cell infiltration into alveolar and interstitial spaces and accumulation of bacteria in the alveolar spaces (H\&E stain, $\times 100)$. (b) Control mouse. Note the presence of inflammatory cell infiltration into interstitial spaces and the mild nature of inflammation relative to that in (a) $(H \& E$ stain, $\times 100)$.

after inoculation (Fig. 4). Similarly, during the early stages of infection $(3,12$ and $24 \mathrm{~h}$ after inoculation), the mean serum IL- $1 \beta$ concentration in IFN- $\gamma^{-/-}$mice was significantly lower than in control mice. Whereas there was no significant difference in serum IL-6 levels between the two groups during the early stages of infection, serum levels in IFN- $\gamma^{-/-}$mice were significantly higher than in control mice during the late stages of infection (24-120 h after inoculation) (Fig. 5). 
a

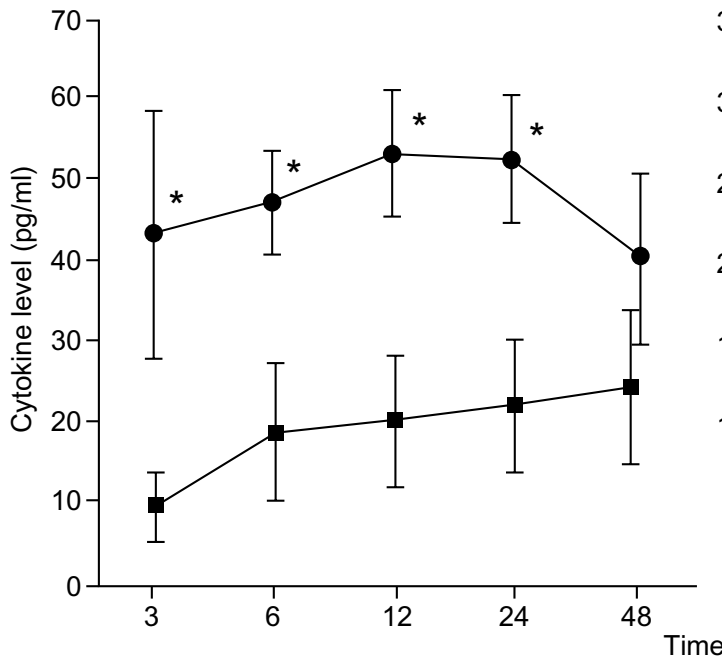

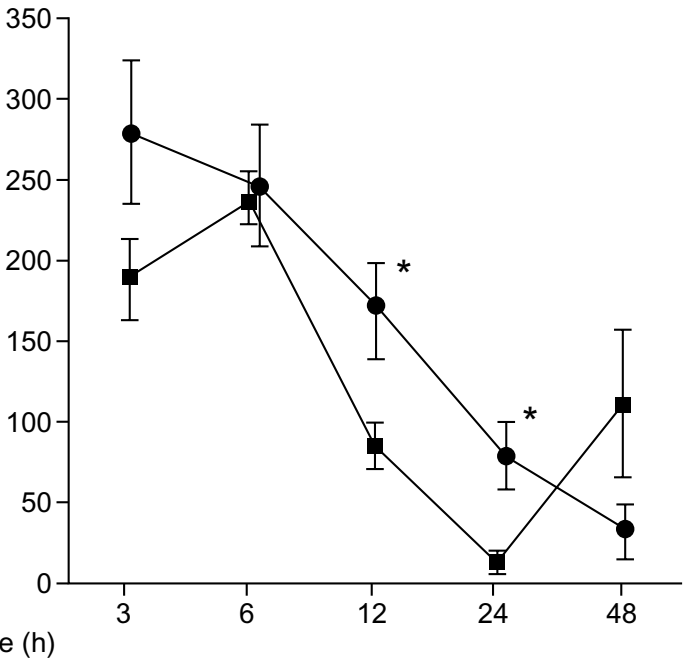

Fig. 4. BALF concentrations of (a) IL- $\beta$ and (b) IL-6 in mice infected with $K$. pneumoniae. Data are mean and SEM values $\left(\mathrm{n}=8\right.$ mice in each group); $\mathbf{\square}, \mathrm{IFN}^{-\gamma^{-}-}$mice; $\boldsymbol{0}$, control mice. ${ }^{*}, \mathrm{p}<0.05$.
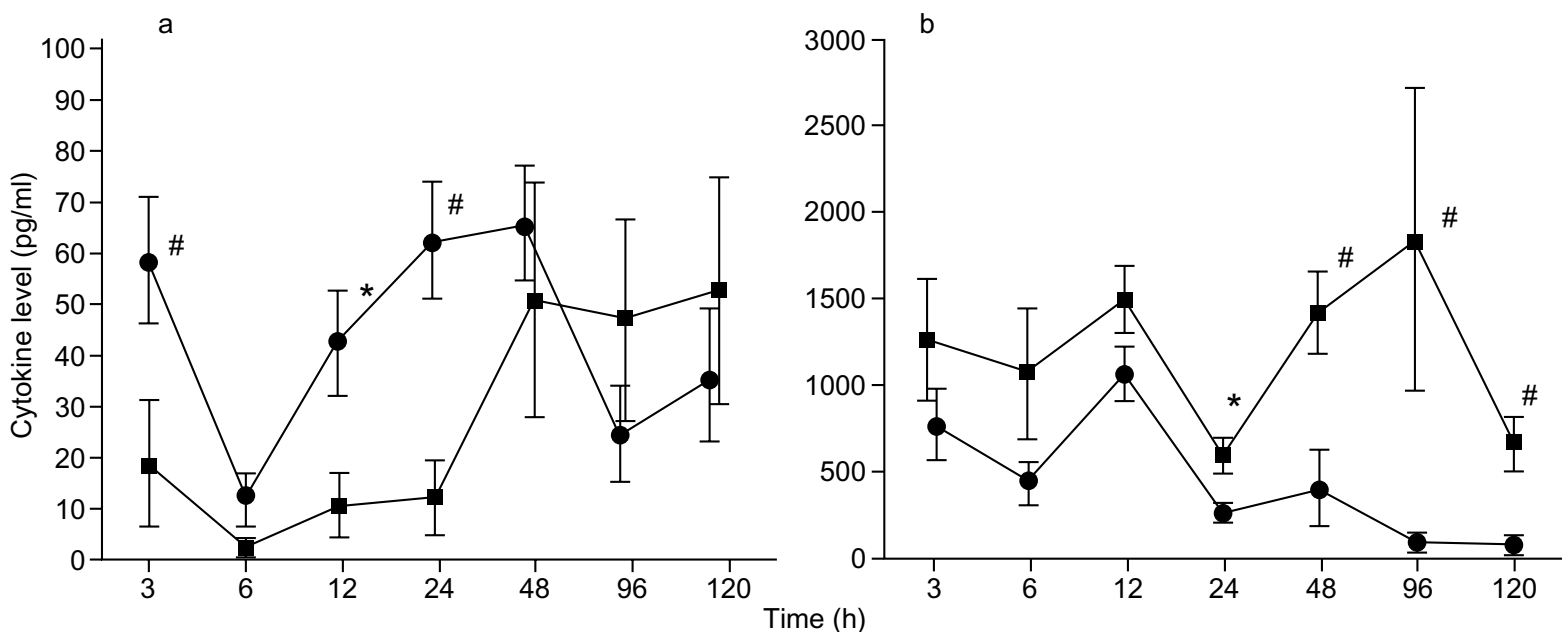

Fig. 5. Serum concentrations of (a) IL- $\beta$ and (b) IL-6 in mice infected with $K$. pneumoniae. Data are mean and SEM values ( $\mathrm{n}=8$ mice in each group); $\mathbf{\square}, \mathrm{IFN}_{-} \gamma^{-/-}$mice; $\boldsymbol{\Theta}$, control mice. ${ }^{*}, \mathrm{p}<0.05, \#, \mathrm{p}<0.01$.

\section{Discussion}

A previous study evaluated the kinetics of tumour necrosis factor (TNF)- $\alpha$, IL- $1 \beta$, IL-6, IFN- $\gamma$ and granulocyte macrophage-colony stimulating factor (GM-CSF) in a murine model of $K$. pneumoniae [18]. During the early stages of infection, the concentrations of TNF- $\alpha$, IL- 6 and IFN- $\gamma$ in BALF of mice infected with a non-capsulate strain were significantly higher than those of mice infected with a capsulate strain [18]. Therefore, it was speculated that these cytokines play a protective role in pulmonary infection with $K$. pneumoniae.

Accumulated evidence derived from a markedly wide spectrum of experimental models of infections suggests that IFN- $\gamma$ is one of the most broadly acting pro-host defence cytokines [19]. The results of the previous study [20] also suggested that IFN- $\gamma$ plays a particularly important role in the induction of other cytokines. Therefore, the present study first investigated the effect of IFN- $\gamma$ on the survival of mice with pneumonia by comparing IFN $-\gamma^{-/-}$and control mice. The results clearly showed that IFN- $\gamma^{-/}$mice were more susceptible to fulminant pulmonary infection with $K$. pneumoniae than control mice.

While IFN- $\gamma$ is probably best recognised as an important macrophage-activating cytokine, it is now clear that this cytokine can also enhance the antimicrobial mechanisms of other leucocytes (including neutrophils) and, at the same time, induce nonprofessional phagocytes to become effective host defence cells. 
The study also demonstrated that viable bacterial counts in lungs and blood of IFN- $\gamma^{-/-}$mice were significantly higher than in control mice. This finding is probably due to reduced function of phagocytic cells in the knockout mice due to the deficiency in IFN- $\gamma$.

In addition to enhancing phagocytic functions, IFN- $\gamma$ also induces the production of other inflammatory cytokines. Therefore, we hypothesised that the deleterious effects of IFN- $\gamma$ deficiency could be mediated by reduced production of other inflammatory cytokines. In this regard, Kolls et al. [12] reported that adenoviralmediated IFN- $\gamma$ gene therapy augmented pulmonary host defence against $K$. pneumoniae in ethanol-treated rats. However, their results demonstrated that enhanced host defences were not reversed by pre-treatment with a polyclonal anti-TNF- $\alpha$ antibody, suggesting that the effect of IFN- $\gamma$ was through a non-TNF- $\alpha$-dependent mechanism. Therefore, the present study investigated the kinetics of an inflammatory cytokine other than TNF- $\alpha$ in the IFN- $\gamma^{-/-}$mouse model.

The results showed significantly lower concentrations of IL- $1 \beta$ and IL- 6 in BALF and IL- $1 \beta$ in serum in IFN$\gamma^{-/-}$mice than in control mice during the early stages of infection. This suggests that IFN- $\gamma$ is involved in host immunological defence against $K$. pneumoniae infection by increasing the production of these inflammatory cytokines both locally at the site of infection and systemically in the peripheral circulation.

Hershman et al. [11] reported that mice pre-treated with IFN- $\gamma$, followed by infection and an additional 2day course of IFN- $\gamma$ treatment, resisted bacterial infection and had a significantly longer survival time than controls in a wound infection model. Furthermore, the survival rate was significantly improved when pretreatment with IFN- $\gamma$ was applied 5 or 3 days, but not 1 day, before experimentally induced infection. Their results suggested that the early phase reactions would affect the outcome of infection. Thus, retardation of immunological reactions in the early phase of infection by deficiency of IFN- $\gamma$ demonstrated in the present study may coincide with the results reported by Hershman et al. [11]. Although there were no differences in serum IL-6 levels between the two groups during the early stages of infection, serum IL-6 concentrations were significantly higher in IFN- $\gamma^{-/-}$ mice than in control mice at the late stage of infection. These results probably reflected the poor condition of mice affected by septicaemia during this stage of infection.

In conclusion, the results of this study of IFN- $\gamma^{-/-}$ mice infected with $K$. pneumoniae suggest that IFN- $\gamma$ is essential to host resistance against $K$. pneumoniae pulmonary infection. The protective action of IFN- $\gamma$ was mediated by activation of phagocytic cells as well as stimulation of production of other inflammatory cytokines.
We are grateful to Shogo Kuwahara for useful advice. We also thank Dr F.G. Issa (Word-Medex, www.word-medex.com.au) for the careful reading and editing of the manuscript.

\section{References}

1. Podschun R, Ullmann U. Klebsiella spp. as nosocomial pathogens: epidemiology, taxonomy, typing methods, and pathogenicity factors. Clin Microbiol Rev 1998; 11: 589-603.

2. Lawrence RC, Komshian S. Gram-negative bacillary pneumonia. Respiratory infection. Pennington JE (eds) Diagnosis and management. New York, Raven Press. 1989: 314-340.

3. Domenico P, Johanson WG, Straus DC. Lobar pneumonia in rats produced by clinical isolates of Klebsiella pneumoniae. Infect Immun 1982; 37: 327-335.

4. Bryan CS, Reynolds KL, Brenner ER. Analysis of 1,186 episodes of gram-negative bacteremia in non-university hospitals: the effects of antimicrobial therapy. Rev Infect Dis 1983; 5: $629-638$.

5. Edelman R, Taylor DN, Wasserman SS et al. Phase 1 trial of a 24-valent Klebsiella capsular polysaccharide vaccine and eightvalent Pseudomonas $O$-polysaccharide conjugate vaccine administered simultaneously. Vaccine 1994; 12: 1288-1294.

6. Standiford TJ, Kunkel SL, Greenberger MJ, Laichalk LL, Strieter RM. Expression and regulation of chemokines in bacterial pneumonia. J Leukoc Biol 1996; 59: 24-28.

7. Greenberger MJ, Strieter RM, Kunkel SL, Danforth JM, Goodman RE, Standiford TJ. Neutralization of IL-10 increases survival in a murine model of Klebsiella pneumonia. $J$ Immunol 1995; 155: 722-729.

8. Greenberger MJ, Kunkel SL, Strieter RM et al. IL-12 gene therapy protects mice in lethal Klebsiella pneumonia. $J$ Immunol 1996; 157: 3006-3012.

9. Held TK, Mielke MEA, Chedid M et al. Granulocyte colonystimulating factor worsens the outcome of experimental Klebsiella pneumoniae pneumonia through direct interaction with the bacteria. Blood 1998; 91: 2525-2535.

10. Zisman DA, Strieter RM, Kunkel SL et al. Ethanol feeding impairs innate immunity and alters the expression of Th1- and Th2-phenotype cytokines in murine Klebsiella pneumonia. Alcohol Clin Exp Res 1998; 22: 621-627.

11. Hershman MJ, Polk HC, Pietsch JD, Kuftinec D, Sonnenfeld G. Modulation of Klebsiella pneumoniae infection of mice by interferon-gamma. Clin Exp Immunol 1988; 72: 406-409.

12. Kolls JK, Lei D, Stoltz D et al. Adenoviral-mediated interferon-gamma gene therapy augments pulmonary host defense of ethanol-treated rats. Alcohol Clin Exp Res 1998; 22: $157-162$.

13. Dalton DK, Pitts-Meek S, Keshav S, Figari IS, Bradley A, Stewart TA. Multiple defects of immune cell function in mice with disrupted interferon-gamma genes. Science 1993; 259: 1739-1742.

14. Wang Z-E, Reiner SL, Zheng S, Dalton DK, Locksley RM. $\mathrm{CD} 4+$ effector cells default to the Th2 pathway in interferon gamma-deficient mice infected with Leishmania major. J Exp Med 1994; 179: 1367-1371.

15. Huang S, Hendriks W, Althage A et al. Immune response in mice that lack the interferon-gamma receptor. Science 1993; 259: $1742-1745$.

16. Rubins JB, Pomeroy C. Role of gamma interferon in the pathogenesis of bacteremic pneumococcal pneumonia. Infect Immun 1997; 65: 2975-2977.

17. Balish E, Wagner RD, Vázquez-Torres A, Pierson C, Warner T. Candidiasis in interferon-gamma knockout (IFN- $\gamma^{-/-}$) mice. $J$ Infect Dis 1998; 178: 478-487.

18. Yoshida K, Matsumoto T, Tateda K, Uchida K, Tsujimoto S, Yamaguchi K. Role of bacterial capsule in local and systemic inflammatory responses of mice during pulmonary infection with Klebsiella pneumoniae. J Med Microbiol 2000; 49: 1003-1010.

19. Murray HW. Current and future clinical applications of interferon-gamma in host antimicrobial defense. Intensive Care Med 1996; 22: S456-S461.

20. Yoshida K, Matsumoto T, Tateda K, Uchida K, Tsujimoto S, Yamaguchi K. Induction of interleukin-10 and down-regulation of cytokine production by Klebsiella pneumoniae capsule in mice with pulmonary infection. J Med Microbiol 2001; 50: 456-461. 